\title{
The Determination of Total
}

\section{Body Exchangeable $\mathrm{O}_{2}$ Stores}

\author{
Carroll E. Cross, Bernard S. Packer, Michael Altman, \\ J. Bernard L. Gee, H. Victor Murdaugh, Jr., and \\ Eugene D. RoBin \\ From the Department of Medicine, University of Pittsburgh Medical School, \\ Pittsburgh, Pennsylvania 15213
}

\begin{abstract}
A в S T R A C T A method is described for the measurement of total body exchangeable oxygen stores $\left(\mathrm{TBO}_{2}\right)$. It is based on the dilution of the stable oxygen isotope, ${ }^{18} \mathrm{O}_{2}$, by the body exchangeable oxygen stores under circumstances in which ${ }^{18} \mathrm{O}_{2}$ is introduced in tracer amounts through a rebreathing circuit. The rate of achieving ${ }^{18} \mathrm{O}_{2}$ steady-state equilibrium was evaluated simultaneously for both arterial and venous blood compartments. After evaluation of several simplifying assumptions, $\mathrm{TBO}_{2}$ values in dog, normal man, and anemic patients were measured. The magnitude of the exchangeable nonlung oxygen stores was $11.0 \pm 3.1 \mathrm{ml} / \mathrm{kg}$ ( $\mathrm{sD}$ ) in 5 dogs, $11.9 \pm 2.1$ $\mathrm{ml} / \mathrm{kg}$ in 10 normal subjects, and $7.0 \pm 1.6 \mathrm{ml} / \mathrm{kg}$ in 8 patients with severe anemia (hematocrits of $25 \%$ or less).
\end{abstract}

\section{INTRODUCTION}

An important variable involved in $\mathrm{O}_{2}$ metabolism is the magnitude of the body stores of $\mathrm{O}_{2}$. The total body exchangeable $\mathrm{O}_{2}$ stores $\left(\mathrm{TBO}_{2}\right)^{1}$ con-

This work was presented in part at the 59th Annual meeting of the American Society for Clinical Investigation, Inc., May 1967.

Received for publication 3 November 1967 and in revised form 17 April 1968

1 The symbols generally used by respiratory physiologists have been used in this paper (2). However, a number of other variables in the present study were assigned symbols as follows: $\mathrm{TBO}_{2}$, total body exchangeable $\mathrm{O}_{2}$ stores in $\mathrm{ml}$ (BTPS); $\mathrm{LO}_{2}$, lung $\mathrm{O}_{2}$ stores in $\mathrm{ml}$ (BTPS); $\mathrm{NLO}_{2}$, Nonlung $\mathrm{O}_{2}$ stores in $\mathrm{ml}$ (BTPS); e.c., external circuit; $t$, time; ${ }^{18} \mathrm{O}_{2}$, isotopic tracer ${ }^{18} \mathrm{O}^{18} \mathrm{O}$, sist of the $\mathrm{O}_{2}$ in lung gas $\left(\mathrm{LO}_{2}\right)$ and the $\mathrm{O}_{2}$ reversibly bound or dissolved in blood and tissues $\left(\mathrm{NLO}_{2}\right)$. These stores provide a reservoir, permitting survival despite temporary interruptions of external $\mathrm{O}_{2}$ supply. Theoretical estimates of the magnitude of $\mathrm{O}_{2}$ stores have been reported (1), but no method for experimental measurement has been available.

We have used an isotope dilution technique, which employed the stable isotope ${ }^{18} \mathrm{O}_{2}\left({ }^{18} \mathrm{O}^{18} \mathrm{O}\right)$, as a tracer to measure $\mathrm{TBO}_{2} \cdot \mathrm{LO}_{2}$ may be determined from the lung volume and mean lung $\mathrm{O}_{2}$ fractional concentration, permitting calculation of $\mathrm{NLO}_{2}$ by subtraction.

This paper will describe a method for the determination of $\mathrm{TBO}_{2}$ and present data on the magnitude of these stores in the dog, normal man, and in anemic patients. In addition, data concerning the rate of achievement of $\mathrm{O}_{2}$ equilibrium and the metabolic properties of ${ }^{18} \mathrm{O}_{2}$ were obtained.

\section{METHODS}

\section{A. Theoretical}

An equation for the determination of $\mathrm{TBO}_{2}$ by a tracer dilution technique may be derived from the law of conservation of mass. At time zero the amount of tracer ${ }^{18} \mathrm{O}_{2}$ in an external circuit (e.c.) is the product of the volume of $\mathrm{O}_{2}$ in the external circuit, $\left[\left(\mathrm{F}^{16} \mathrm{O}_{2} \cdot \mathrm{V}\right)_{\text {e.c. }}\right]_{t=0}$, and the initial fractional ratio of the isotopic species of $\mathrm{O}_{2}$ in this volume,

mass $36 ;{ }^{16} \mathrm{O}_{2}$, normal species of ${ }^{16} \mathrm{O}^{16} \mathrm{O}$, mass $32 ; \mathrm{FO}_{2}$, fractional concentration of $\mathrm{O}_{2}(\mathrm{ml} / \mathrm{ml}) ; r$, fractional ratio of ${ }^{18} \mathrm{O}_{2}$, i.e., $\mathrm{F}^{18} \mathrm{O}_{2} /\left(\mathrm{F}^{18} \mathrm{O}_{2}+\mathrm{F}^{16} \mathrm{O}_{2}\right)$; when ${ }^{18} \mathrm{O}_{2}$ is present in trace amounts $\left(\mathrm{F}^{18} \mathrm{O}_{2}<\mathrm{F}^{18} \mathrm{O}_{2}\right)$ this may be operationally defined as $\mathrm{F}^{18} \mathrm{O}_{2} / \mathrm{F}^{18} \mathrm{O}_{2}$. 
$\left(r_{\text {e.c. }}\right)_{t}-0$. There is no measurable ${ }^{18} \mathrm{O}_{2}$ in the initial exchangeable body $\mathrm{O}_{2}$ stores, $\left(\mathrm{TBO}_{2}\right)_{t}=0$. At equilibrium, after a period of rebreathing, fractional ratios of $\mathrm{O}_{2}$ species, $(r)_{t}$ =equilibrium, are identical in both the $\mathrm{O}_{2}$ volume remaining in the external circuit, $\left[\left(\mathrm{F}^{16} \mathrm{O}_{2} . \mathrm{V}\right)_{\text {e.c. }}\right]_{t}=$ equilibrium, and the exchangeable body $\mathrm{O}_{2}$ stores, $\left(\mathrm{TBO}_{2}\right)_{t}=$ equilibrium. Thus, if $\mathcal{S}_{t=0}^{t-e q u i l i b r i u m} \mathrm{~V}^{18} \mathrm{O}_{2} \mathrm{dt}$ represents the ${ }^{18} \mathrm{O}_{2}$ consumption during the period of equilibration, the following equation may be written :

$$
\begin{gathered}
\left(r_{\text {e.c. }}\right)_{t}=0 \times\left[\left(\mathrm{F}^{16} \mathrm{O}_{2} \cdot \mathrm{V}\right)_{\text {e.c. }}\right]_{t=0}=\left(r_{\text {e.c. }}\right)_{t}-\text { equilibrium } \\
\times\left\{\left[\left(\mathrm{F}^{16} \mathrm{O}_{2} \cdot \mathrm{V}\right)_{\text {e.c. }}\right]_{t}=\right.\text { equilibrium } \\
\left.+\left(\mathrm{TBO}_{2}\right)_{t}=\text { equilibrium }\right\}+\mathcal{S}_{t=0}^{t}=\mathbf{e q u i l i b r i u m} \mathrm{V}^{18} \mathrm{O}_{2} \mathrm{dt}
\end{gathered}
$$

An analogous equation for ${ }^{16} \mathrm{O}_{2}$ may be written as

$$
\begin{gathered}
{\left[\left(\mathrm{F}^{16} \mathrm{O}_{2} \cdot \mathrm{V}\right)_{\text {e.c. }}\right]_{t}=0+\left(\mathrm{TBO}_{2}\right)_{t}=0} \\
=\left[\left(\mathrm{F}^{16} \mathrm{O}_{2} \cdot \mathrm{V}\right)_{\text {e.c. }}\right]_{t}=\text { equilibrium } \\
+\left(\mathrm{TBO}_{2}\right)_{t}-\text { equilibrium } \\
+\mathcal{S}_{t}^{t}=0
\end{gathered}
$$

Combining equations 1 and 2, eliminating

$$
\left(\mathrm{TBO}_{2}\right)_{t} \text { - equilibrium }
$$

and solving for $\left(\mathrm{TBO}_{2}\right)_{t=0}$ yields

$$
\begin{aligned}
& \left(\mathrm{TBO}_{2}\right)_{t}=0 \\
& =\left[\left(\mathrm{F}^{16} \mathrm{O}_{2} \cdot \mathrm{V}\right)_{\text {e.c. }}\right]_{t}=0\left(\frac{\left(r_{\text {e.c. }}\right)_{t=0}}{\left(r_{\text {e.c. }}\right)_{t}=\text { equilibrium }}-1\right) \\
& \quad+\int_{t=0}^{t=\text { equilibrlum }} \dot{\mathrm{V}}^{16} \mathrm{O}_{2} \mathrm{dt} \\
& \quad-\frac{1}{\left(r_{\text {e.c. }}\right)_{t}=\text { equilibrium }} \int_{t=0}^{t=\text { equilibrium }} \dot{\mathrm{V}}^{18} \mathrm{O}_{2} \mathrm{dt}
\end{aligned}
$$

In equation $3,\left[\left(\mathrm{~F}^{16} \mathrm{O}_{2} \cdot \mathrm{V}\right)_{\text {e.c. }}\right]_{t=0}$ may be readily determined. $\left(r_{\text {e.c. }}\right)_{t}=0$ and $\left(r_{\text {e.c. }}\right)_{t}=$ equilibrium are obtained by mass spectrometry. $\int_{t=0}^{t=\text { equilibrium }} \dot{\mathrm{V}}^{16} \mathrm{O}_{2} \mathrm{dt}$, the total ${ }^{16} \mathrm{O}_{2}$ consumption during the experimental period, is measured by the closed circuit method and is assumed to be constant during the equilibration period. Evaluation of the right hand integral term, $\boldsymbol{S}_{t=0}^{t=\text { equilibrium }} \dot{\mathrm{V}}^{18} \mathrm{O}_{2} \mathrm{dt}$, the ${ }^{18} \mathrm{O}_{2}$ consumption during the experimental period, presents considerable difficulties, and in fact cannot be directly measured (see below). However, in the absence of significant isotopic fractionation (see Discussion), the total $\mathrm{O}_{2}$ consumption may be apportioned between the ${ }^{18} \mathrm{O}_{2}$ and ${ }^{16} \mathrm{O}_{2}$ species on the basis of their fractional concentrations at the sites of $\mathrm{O}_{2}$ utilization in the cells. Thus, the ${ }^{18} \mathrm{O}_{2}$ consumption may be written as

$$
\dot{\mathrm{V}}^{18} \mathrm{O}_{2}=\left(\bar{r}_{\mathrm{cell}}\right) \times \dot{\mathrm{V}}^{16} \mathrm{O}_{2}
$$

where $\left(\bar{r}_{\text {cells }}\right)$ represents the mean oxygen ratios at cellular $\mathrm{O}_{2}$ consumption sites during the experimental period.

The precise values of $\left(r_{\text {oells }}\right)$ at any given time at the cellular utilization sites cannot be measured directly. However, the magnitude of the ${ }^{18} \mathrm{O}_{2}$ consumption term of equation 3 , and its effects on the calculation of $\mathrm{TBO}_{2}$, may be approached by the comparison of two methods.

(1) The range of ${ }^{18} \mathrm{O}_{2}$ consumption during the experimental period may be approximated by determining the maximal and minimal values of ${ }^{18} \mathrm{O}_{2}$ consumption. The limits may be derived from the reasonable assumption that, at any given time, $\left(r_{\mathrm{ce} l l_{s}}\right)$ lies between arterial and mixed venous isotopic $\mathrm{O}_{2}$ ratios, $\left(r_{\mathbf{a}}\right)$ and $\left(r_{\bar{v}}\right)$. Thus, serial measurements of $\left(r_{\mathrm{a}}\right)$ and $\left(r_{\overline{\mathrm{v}}}\right)$ were obtained during the rebreathing period and their respective means, $\left(\dot{r}_{\mathrm{a}}\right)$ and $\left(\bar{r}_{\bar{v}}\right)$, calculated by graphic integration. The ${ }^{18} \mathrm{O}_{2}$ consumption was assumed to lie between $t \times \dot{\mathrm{V}}^{16} \mathrm{O}_{2} \times\left(\tilde{r}_{\mathrm{a}}\right)$, a maximum, and $t \times \dot{\mathrm{V}}^{16} \mathrm{O}_{2} \times\left(\bar{r}_{\mathrm{v}}\right)$, a minimum. Limits could thus be placed on equation 3 as follows

minimum $\mathrm{TBO}_{2}$

$$
\begin{array}{r}
=\left[\left(\mathrm{F}^{16} \mathrm{O}_{2} \cdot \mathrm{V}\right)_{\text {e.c. }}\right]_{t}=0\left(\frac{\left(\mathrm{r}_{\text {e.c. }}\right)_{t=0}}{\left(\mathrm{r}_{\text {e.c. }}\right)_{t}=\text { equilibrium }}-1\right) \\
+t \times \dot{\mathrm{V}}^{16} \mathrm{O}_{2} \times\left(1-\frac{\left(\bar{r}_{\mathrm{a}}\right)}{\left(r_{\text {e.e. }}\right)_{t-\text { equilibrium }}}\right)
\end{array}
$$

maximum $\mathrm{TBO}_{2}$

$$
\begin{array}{r}
=\left[\left(\mathrm{F}^{16} \mathrm{O}_{2} \cdot \mathrm{V}\right)_{\text {e.c. }}\right]_{t}=0\left(\frac{\left(\mathrm{r}_{\text {e.c. }}\right)_{t-0}}{\left(\mathrm{r}_{\text {e.c. }}\right)_{t=\text { equilibrium }}}-1\right) \\
+t \times \dot{\mathrm{V}}^{16} \mathrm{O}_{2} \times\left(1-\frac{\left(\bar{r}_{\mathrm{v}}\right)}{\left(\mathrm{r}_{\text {e.c. }}\right)_{t}=\text { equilibrium }}\right)
\end{array}
$$

(2) The simplifying assumption of instantaneous ${ }^{18} \mathrm{O}_{2}$ distribution throughout $\mathrm{TBO}_{2}$ could be made (see Discussion). The $\dot{\mathrm{V}}^{18} \mathrm{O}_{2}$ depends only on the equilibrium isotopic

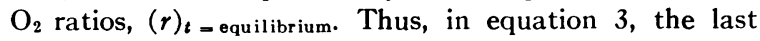
two terms become equal and the equation reduces to the simple dilution equation with instantaneous equilibrium :

$$
\begin{aligned}
\mathrm{TBO}_{2}=\left[\left(\mathrm{F}^{16} \mathrm{O}_{2} \cdot \mathrm{V}\right)_{\text {e.c. }}\right]_{t} & =0 \\
& \times\left(\frac{\left(\mathrm{r}_{\text {e.c. }}\right)_{t-0}}{\left(\mathrm{r}_{\text {e.c. }}\right)_{t}=\text { equilibrium }}-1\right)
\end{aligned}
$$

All of the terms on the right hand side of equation 7 have values which are easily measured so that, by this method of approximation, $\mathrm{TBO}_{2}$ may be readily assessed.

\section{B. Experimental}

A closed rebreathing circuit consisting of a 5-liter rebreathing bag connected to a $\mathrm{CO}_{2}$ absorber was used (Fig. 1). Rebreathing system gas could be obtained for

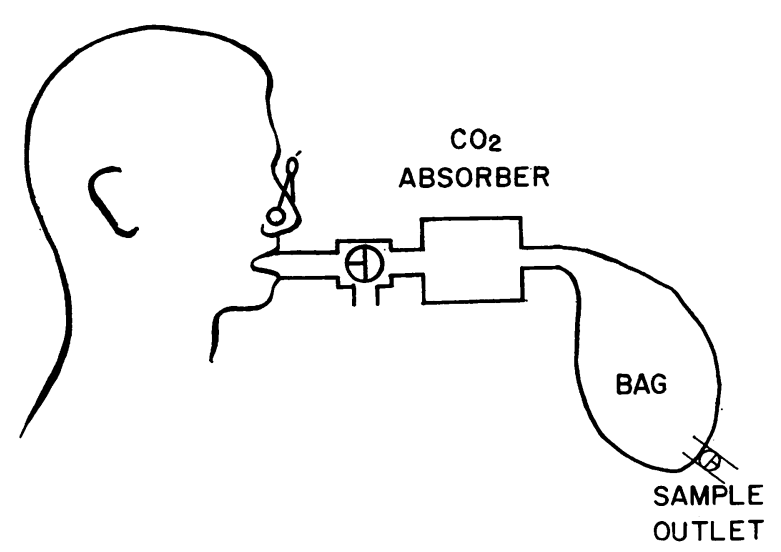

FIGURE 1 Diagrammatic representation of the rebreathing apparatus. Samples were collected from the bag into a vacuum line, thence to tonometers via the sample outlet. 
analysis at any time through the sampling tap. The rebreathing bag was initially filled with ${ }^{16} \mathrm{O}_{2}(55-95 \%),{ }^{2}$ neon $(1-2 \%),{ }^{18} \mathrm{O}_{2}(0.4-1.5 \%),{ }^{3}$ and the balance nitrogen. The subject was connected to the apparatus and, after an adjustment period of breathing room air, was connected to the rebreathing system.

(a) Calculation of lung volumes and ${ }^{10} \mathrm{O}_{2}$ consumptions. In man, studies were initiated and completed at the same lung volumes ( $V_{\text {lung }}$ ), this volume being the residual lung volume. Since $\mathrm{CO}_{2}$ was absorbed and since $\left(V_{\text {e.c. }}\right)_{t=0}$ and $\left(V_{\text {e.c. }}\right)_{t=\text { equilibrium }}$ were measured, lung volume could be calculated by the dilution of neon (3). In the determinations in dogs it could not be assumed that initial and equilibrium lung volumes were identical: it was, therefore, necessary to use a double dilution technique, using the initial external circuit neon and initial lung argon or nitrogen dilutions and solving for the initial lung volume. ${ }^{4} \mathrm{LO}_{2}$, the initial lung $\mathrm{O}_{2}$ store, is the product of the lung volume and the mean lung $\mathrm{O}_{2}$ fractional gas concentration. Since we did not determine the mean $\mathrm{O}_{2}$ of the lung gas, the fractional concentration of 0.15 was used (1). $\mathrm{LO}_{2}$ was then defined as the determined $\mathrm{V}_{\text {lung }} \times 0.15$. The ${ }^{16} \mathrm{O}_{2}$ consumption was calculated assuming that, when $\mathrm{CO}_{2}$ is absorbed in the external circuit, the only gas which is lost from the system in significant quantities is ${ }^{10} \mathrm{O}_{2}$. For the animal studies, where changes in initial and equilibrium lung volumes occurred, the change in lung volume was taken into account.

(b) Subjects. Five mongrel dogs $(11-28 \mathrm{~kg})$ were studied. They were anesthetized with sodium pentobarbital $(20 \mathrm{mg} / \mathrm{kg})$ and a cuffed endotracheal tube was inserted. Catheters were then introduced into a branch of the femoral artery and under fluoroscopic control into the pulmonary artery. During the experimental period the dogs were ventilated by a Ruben valve and 5-liter bag. In these preparations the rebreathing system gas, arterial and mixed venous blood $\mathrm{O}_{2}$ isotopic ratios, $\left(r_{\text {e.e. }}\right)$, $\left(r_{\mathrm{a}}\right)$, and $\left(r_{\mathrm{v}}\right)$, were examined at varying times.

10 normal humans $(57-79 \mathrm{~kg})$ were studied. They were connected to the external system while at residual lung volumes, and initially respired with moderate hyperventilation so as to mix the alveolar and external rebreathing bag oxygen rapidly. In many of the studies peripheral venous samples were also drawn during the period of equilibration.

Eight anemic patients $(42.5-102.5 \mathrm{~kg})$ with various types of anemia were selected for study, since a decrease

${ }^{2}$ Large fractional ${ }^{18} \mathrm{O}_{2}$ concentrations in the external circuit were used to allow for both rapid mixing of external circuit and lung gas, and yet allow studies to progress as long as necessary.

3 Obtained as $93 \%$ atom ${ }^{18} \mathrm{O}(86 \%$ mass 36$)$ from Yeda Research and Development, Weizmann Institute, Rehovoth, Israel.

4 The assumption that initial lung volume was filled with air concentrations of $\mathrm{N}_{2}(0.788)$ and $\operatorname{Ar}(0.0094)$ was made. This assumption is only approximate as RQ was not determined; the error is estimated to be smaller than the reproducibility of the measurement ( $\pm 10 \% \mathrm{SD})$. in red cell mass must decrease $\mathrm{TBO}_{2}$. These patients had hematocrits of $19-25 \%$ and no demonstrable lung disease. Studies were performed in the same manner as in the normal group.

(c) Analytical. The external gas volumes were measured with a spirometer. Aliquots of this gas volume were transferred into evacuated tonometers and subsequently analyzed with a Model 21-103C Consolidated Electrodynamics mass spectrometer. Masses in the range 20-44 were scanned. From the relative intensity of ions mass 36 and mass 32 , the tracer ${ }^{18} \mathrm{O}_{2}$ isotopic ratios were calculated (as peak height 36/peak height 32). Peak heights 20,28, 40, and 44 represented $\mathrm{Ne}, \mathrm{N}_{2}, \mathrm{Ar}$, and $\mathrm{CO}_{2}$, respectively. ${ }^{5}$ Mass peaks were calibrated against gas standards and could be converted to partial pressures or fractional concentrations. Instrument response was linear, with respect to gas partial pressures for all species considered. Background, sensitivity, and stability were frequently checked, the latter being better than $0.25 \%$ absolute standard deviation for all gases analyzed. The instrument was capable of measuring $\mathrm{F}^{18} \mathrm{O}_{2} / \mathrm{F}^{16} \mathrm{O}_{2}$ to standard deviations of approximately $0.2 \%$ at concentration levels of $1 \%{ }^{18} \mathrm{O}_{2}$. All gas samples were collected and analyzed in at least duplicate, and a reproducibility in the over-all analysis of $0.5 \%$ was readily obtained.

Blood samples $(5 \mathrm{ml})$ were collected anaerobically in plastic syringes and transferred immediately to rubberstoppered evacuated glass tonometers, which contained a drop of Triton X100 and a small amount of potassium ferrocyanide, and sealed. The evolved gas was conducted through an acetone-dry ice cold trap vacuum line to trap water vapor and then directly into the ionization chamber of the mass spectrometer. Masses in the range 20-44 were again scanned and analyzed in the usual manner. ${ }^{6}$ Room air contamination, and thus, atmospheric dilution of ${ }^{18} \mathrm{O}_{2}$, was readily detected by monitoring peaks 28 (nitrogen) or 40 (argon). Contaminated samples were discarded. Isotopic analysis was performed immediately after the experiment. The reproducibility of the isotopic $\mathrm{O}_{2}$ analysis on duplicate blood samples was $\pm 1 \%$.

\section{RESULTS}

As indicated earlier, the calculation of $\mathrm{TBO}_{2}$ depends upon the method employed for the assess-

5 A non- $\mathrm{O}_{2}$ reacting filament (rhenium) was used in the ionization chamber of the mass spectrometer. Correction factors were determined for each series of measurements. The correction factor applied to peak 36 due to isotopic $\mathrm{Ar}^{+}$(mass 36) was 0.0033 of the 40 peak (amounting to approximately $1 \%$ of the total peak 36 ) ; peak 20 due to $\mathrm{Ar}^{++}$(mass 40) was approximately 0.140 of the 40 peak; peak 28 due to $\mathrm{CO}^{+}$(mass 28) was approximately 0.106 of the 44 peak.

${ }^{6}$ The natural abundance of ${ }^{18} \mathrm{O}_{2}\left({ }^{18} \mathrm{O}^{18} \mathrm{O}\right)$ is 0.000004 (4). As this was beyond detection by the methods used in this investigation, no additional background corrections of the 36 peak were required for either gas or blood samples. 
ment of ${ }^{18} \mathrm{O}_{2}$ consumption during the equilibration period. For this reason, the data are presented to indicate the effects on $\mathrm{TBO}_{2}$ of the delay in ${ }^{18} \mathrm{O}_{2}$ equilibrium during the rebreathing process, as approximated by equations 5 and 6 . Finally, data are presented that permit a comparison of $\mathrm{TBO}_{2}$ and $\mathrm{NLO}_{2}$ in normal subjects and in anemic patients.

A. ${ }^{18} \mathrm{O}_{2}$ equilibration rates and the calculation of $\mathrm{TBO}_{2}$ in the dog. This method requires the demonstration of equilibration of ${ }^{18} \mathrm{O}_{2}$ throughout all ${ }^{18} \mathrm{O}_{2}$ containing compartments. Further, since ${ }^{18} \mathrm{O}_{2}$ is distributed throughout the body stores and also consumed by the tissues, the ${ }^{18} \mathrm{O}_{2}$ consumption term in equation 3 requires assessment. Representative data from studies in five dogs, in which measurements of external rebreathing system, arterial, and mixed venous isotopic $\mathrm{O}_{2}$ ratios were obtained during the 5-20 min rebreathing periods, are shown in Fig. 2. The standardized isotopic $\mathrm{O}_{2}$ ratios are plotted vs. time (see below). These data indicate the following.

(a) No significant changes in $\left(r_{\text {e.c. }}\right)$, the isotopic $\mathrm{O}_{2}$ ratios in the external rebreathing system,
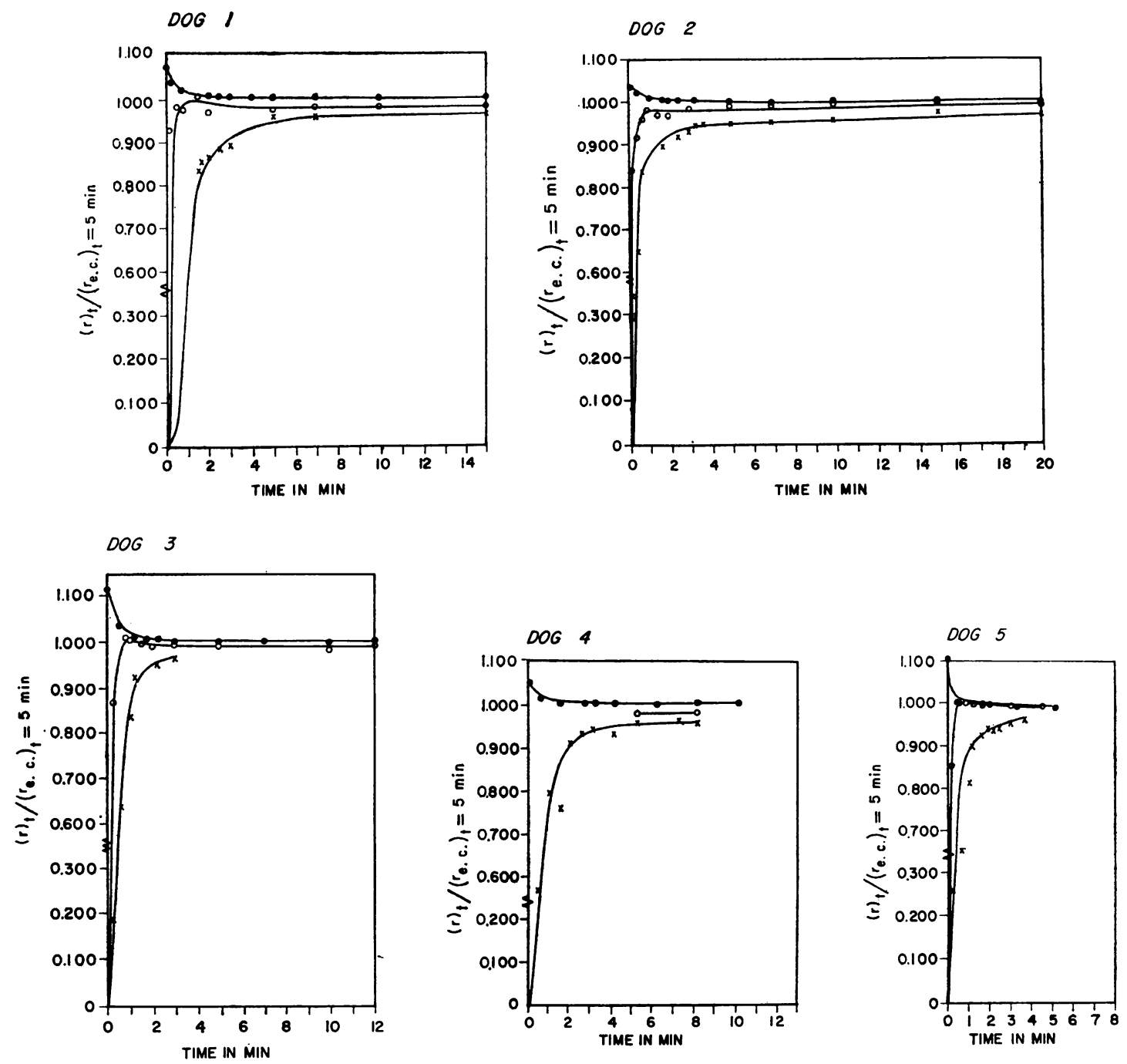

FIgURE 2 Time course of ${ }^{18} \mathrm{O}_{2}$ equilibration in external circuit, arterial, and mixed blood. $(r)_{t} /\left(r_{\text {e.c. }}\right)_{t}=5 \mathrm{~min}$, the normalized ${ }^{18} \mathrm{O}_{2}$ fractional isotopic ratios, are plotted vs. time. Curves shown are $\left(r_{\text {e.c. }}\right)_{t} /\left(r_{\text {e.c. }}\right)_{t}=5 \mathrm{~min},\left(r_{\mathrm{a}}\right)_{t} /$ $\left(r_{\text {e.c. }}\right)_{t}-5 \mathrm{~min}$, and $\left(r_{\overline{\mathrm{v}}}\right)_{t} /\left(r_{\text {e.c. }}\right)_{t}-5 \mathrm{~min}$ and are represented by $(-0),(0-0)$, and $(\mathrm{X}-\mathrm{X})$, respectively. $\left(\tilde{r}_{\mathrm{a}}\right)_{t=0-5 \mathrm{~min}} /\left(r_{\text {e.c. }}\right)_{t}=5 \mathrm{~min}$ and $\left(\tilde{r}^{-}\right)_{t=0-5 \min } /\left(r_{\text {e.c. }}\right)_{t}=5 \mathrm{~min}$ were determined over the initial 5 -min period except for $\operatorname{dog} 4$, where enough points did not exist to allow estimation of $\left(\tilde{r}_{\mathrm{a}}\right)_{t}-0-5 \min /\left(r_{0 . c}\right)_{t}-5 \min$. 
TABLE I

$\mathrm{TBO}_{2}$ Determinations in Dogs by Three Methods of Approximation

\begin{tabular}{|c|c|c|c|c|c|c|c|c|c|c|c|c|c|c|c|c|c|}
\hline \multirow{2}{*}{$\begin{array}{l}\text { Dog } \\
\text { No. }\end{array}$} & \multirow[b]{2}{*}{ Wt } & \multirow{2}{*}{$\begin{array}{l}\text { Length } \\
\text { of } \\
\text { study }\end{array}$} & \multirow[b]{2}{*}[(\mathrm{F}^{16}\mathrm{O}_{2}\mathrm{V})\text{e.c.}]{$t-0$} & \multicolumn{3}{|c|}{$\left(r_{\text {e.c. }}\right) t=0\left(\bar{r}_{\mathrm{a}}\right) t-0 \rightarrow 5\left(\bar{r}_{\bar{v}}\right) t-0-5$} & \multirow[b]{2}{*}{$\dot{\mathrm{V}}^{16} \mathrm{O}_{2}$} & \multicolumn{3}{|c|}{$\begin{array}{r}\mathrm{TBO}_{2} \\
(\mathrm{ml}, \mathrm{BTPS})\end{array}$} & \multirow{2}{*}{$\begin{array}{c}\mathrm{LO}_{2} \\
(\mathrm{ml}, \mathrm{BTPS})\end{array}$} & \multicolumn{3}{|c|}{$\begin{array}{c}\mathrm{NLO}_{2} \\
(\mathrm{ml}, \mathrm{BTPS})\end{array}$} & \multicolumn{3}{|c|}{$\begin{array}{c}\mathrm{NLO}_{2} / \mathrm{kg} \\
(\mathrm{ml}, \mathrm{BTPS} \\
\mathrm{kg})\end{array}$} \\
\hline & & & & $\left(r_{\text {e.c. }}\right) t-s$ & $\left(r_{\text {e.c. }}\right) t=b$ & $\left(r_{\text {e.c. }}\right) \triangleleft-5$ & & (1) & (2) & (3) & & (1) & (2) & (3) & (1) & & (3) \\
\hline & $\mathrm{kg}$ & & & & & & $\mathrm{ml} / \mathrm{min}$ & & & & & & & & & & \\
\hline 1 & 12 & 15 & 2.7 & 1.073 & 0.970 & 0.791 & 100 & 225 & 315 & 210 & 95 & 130 & 220 & 115 & 12 & 23 & 10 \\
\hline 2 & 11 & 12 & 3.6 & 1.037 & 0.946 & 0.859 & 120 & 175 & 230 & 145 & 60 & 115 & 170 & 85 & 10 & 16 & 8 \\
\hline 3 & 28 & 20 & 3.4 & 1.113 & 0.975 & 0.838 & 140 & 430 & 525 & 410 & 200 & 230 & 325 & 210 & 9 & 16 & 8 \\
\hline 4 & 13 & 10 & 4.2 & 1.052 & & 0.837 & 140 & & 350 & 235 & 60 & & 290 & 175 & & 28 & 13 \\
\hline 5 & 26 & 5 & 3.8 & 1.166 & 0.954 & 0.861 & 150 & 715 & 785 & 680 & 260 & 455 & 525 & 420 & 18 & 21 & 16 \\
\hline Mea & $n(4 \mathrm{~d}$ & & & & & & & & & & & & & & 12 & 19 & 11 \\
\hline
\end{tabular}

$\left[\left(\mathrm{F}^{16} \mathrm{O}_{2} \mathrm{~V}\right)_{\text {e.c. }}\right]_{t}-0$ represents the initial volume of ${ }^{16} \mathrm{O}_{2}$ in an external circuit. $\left(r_{\text {e.c. }}\right) t-0,\left(r_{\mathbf{e} . c .}\right) t-5,\left(\bar{r}_{\mathrm{a}}\right) t-0-5$, and $\left(\bar{r}_{\vec{v}}\right) t-0-5$ represent ${ }^{18} \mathrm{O}_{2}$ iractional isotopic ratios in the initial external circuit, in the external circuit at $5 \mathrm{~min}$, the mean in the arterial compartment from $0-5$ min and the mean in the pulomonary artery trom $0-5 \mathrm{~min}$, respectively. $\dot{\mathrm{V}}^{16} \mathrm{O}_{2}$ represents the ${ }^{16} \mathrm{O}_{2}$ consumption rate during the study, TBO $2(1), \mathrm{TBO}_{2}(2)$, $\mathrm{TBO} \mathrm{O}_{2}(3)$ and $\mathrm{NLO}_{2}(1), \mathrm{NLO}_{2}(2)$, and $\mathrm{NLO}_{2}(3)$ the exchangeable body $\mathrm{O}_{2}$ stores and nonlung stores calculated by equations 5-7, respectively, and $\mathrm{LO} 2$ represents the calculated lung ${ }^{16} \mathrm{O}_{2}$ stores. Note that no $\left(\bar{r}_{\mathrm{a}}\right)_{t}-0-5$ was available in $\operatorname{dog} .4$.

were found after $5 \mathrm{~min}$. This value was therefore

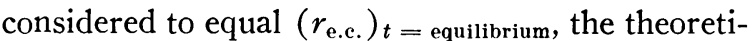
cal equilibrium steady state $\mathrm{O}_{2}$ isotopic ratios in the external circuit. For comparative purposes $\left(r_{\text {e.c. }}\right)$, $\left(r_{\mathbf{a}}\right)$, and $\left(r_{\bar{v}}\right)$ are expressed as fractional values of this $\left(r_{\text {e.c. }}\right)_{t=\text { equilibrium, as shown in Fig. } 2 .}$

(b) During the early rebreathing period $\left(r_{\mathbf{a}}\right)$ rapidly approaches $\left(r_{\text {e.c. }}\right)$. After $5 \mathrm{~min}\left(r_{\mathrm{a}}\right)$ averaged 0.99 and $\left(r_{\overline{\mathrm{v}}}\right)$ averaged 0.965 of the average values in $\left(r_{\text {e.c. }}\right)$.

$\mathrm{TBO}_{2}$ was calculated by the three methods discussed in equations 5-7 and are shown in Table I. $\left(\bar{r}_{\mathbf{a}}\right)$ and $\left(\bar{r}_{\overline{\mathbf{v}}}\right)$ were calculated by graphic integration and represent 5 min means of $\left(r_{\mathbf{a}}\right)$ and $\left(r_{\bar{v}}\right)$, respectively. 5 min was arbitrarily chosen because $\left(r_{\text {e.c. }}\right)$ was at apparent equilibrium by this time. ${ }^{16} \mathrm{O}_{2}$ consumption was directly measured and $\mathrm{LO}_{2}$ calculated as described in Methods. The $\mathrm{LO}_{2}$ values were subsequently subtracted from the $\mathrm{TBO}_{2}$ values and $\mathrm{NLO}_{2}$ calculated by the three methods with equation 5 (a minimum), equation 6 (a maximum), and equation 7 (the simplified method).

The range of $\mathrm{TBO}_{2}$ calculated by the three methods is evident, $\mathrm{TBO}_{2}$ (1) and $\mathrm{TBO}_{2}$ (2) exceeding those calculated on the basis of the simplifying assumption of instantaneous equilibration by 7 and $28 \%$, respectively. The analogous $\mathrm{NLO}_{2}$ (1) and $\mathrm{NLO}_{2}$ (2) determinations exceeded $\mathrm{NLO}_{2}$ (3) by 12 and $50 \%$, respectively.

B. 5 min equilibration in a peripheral venous compartment in man. Mixed venous blood was not obtained in the human studies. However, blood was obtained from an arm vein at $5 \mathrm{~min}$ in 11 of the normal human studies and the results are shown in Table II. The $\left(r_{\mathrm{v}}\right) /\left(r_{\text {e.c. }}\right) 5$ min values from the peripheral vein blood were essentially equal to the $\left(r_{\overline{\mathbf{v}}}\right) /\left(r_{\text {e.c. }}\right) 5 \mathrm{~min}$ values from the pulmonary artery blood of the four dogs shown in Fig. 2 ( 0.96 and 0.965 , respectively).

C. $\mathrm{TBO}_{2}$ in normal and anemic man. Table III presents values for $\mathrm{TBO}_{2}$ and $\mathrm{NLO}_{2}$ in the normal subjects and the anemic patients. The values for $\mathrm{TBO}_{2}$ were calculated from equation 7 . Nonlung $\mathrm{O}_{2}$ stores in $\operatorname{dog}(11.0 \mathrm{ml} / \mathrm{kg})$ and normal man

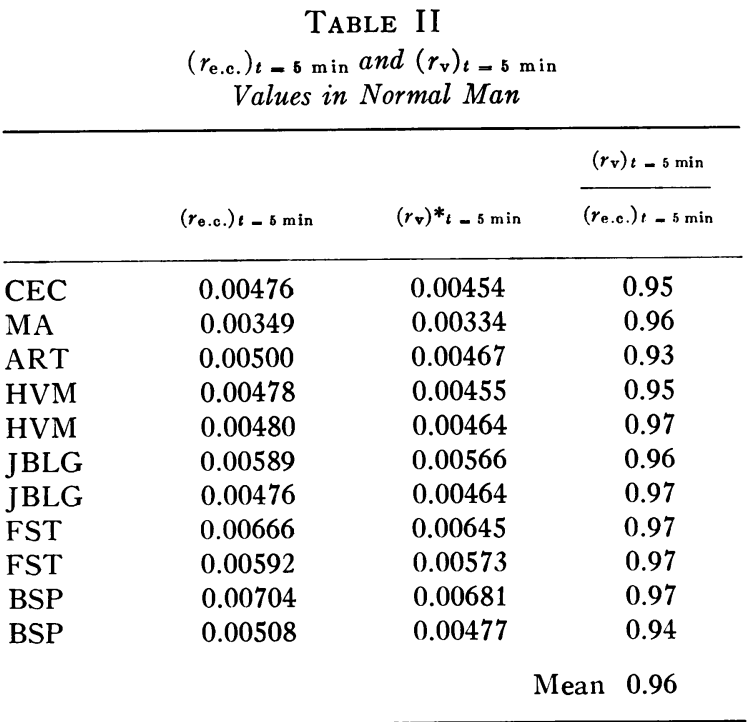

As $\left(r_{\text {e.c. }}\right)$ did not change significantly after $5 \mathrm{~min}$, it is operationally identical to $\left(r_{\text {e.c. }}\right)_{t}$ - equilibrium (see Discussion). * $\left(r_{\mathrm{v}}\right)$, isotope ratio in brachial venous blood. 
TABLE III

Exchangeable $\mathrm{O}_{2}$ Stores in 10 Normal Males and 8 Anemic Patients

\begin{tabular}{|c|c|c|c|c|c|c|c|}
\hline Subject & Het & $\begin{array}{l}\text { No. of } \\
\text { studies }\end{array}$ & $\mathrm{Wt}$ & $\mathrm{TBO}_{2}$ & $\mathrm{LO}_{2}$ & $\mathrm{NLO}_{2}$ & $\mathrm{NLO}_{2} / \mathrm{kg}$ \\
\hline & $\%$ & & $(k g)$ & liter & liter & liter & $(\mathrm{ml} / \mathrm{kg})$ \\
\hline CEC & Normal & 8 & 72 & 1.19 & 0.22 & 0.97 & 13 \\
\hline JBLG & Normal & 3 & 80 & 1.05 & 0.31 & 0.74 & 9 \\
\hline MA & Normal & 3 & 79 & 1.29 & 0.50 & 0.79 & 10 \\
\hline BSP & Normal & 2 & 74 & 1.26 & 0.22 & 1.04 & 15 \\
\hline ART & Normal & 2 & 68 & 1.23 & 0.39 & 0.84 & 13 \\
\hline HVM & Normal & 2 & 79 & 1.06 & 0.34 & 0.72 & 9 \\
\hline FST & Normal & 2 & 75 & 1.37 & 0.40 & 0.97 & 13 \\
\hline RMP & Normal & 2 & 70 & 1.02 & 0.30 & 0.72 & 10 \\
\hline DLM & Normal & 2 & 61 & 1.04 & 0.18 & 0.86 & 14 \\
\hline JFY & Normal & 2 & 61 & 0.98 & 0.20 & 0.78 & 13 \\
\hline $\begin{array}{l}\text { Mean } \\
\text { SD }\end{array}$ & & & 72 & $\begin{array}{l}1.15 \\
0.13\end{array}$ & 0.31 & 0.84 & $\begin{array}{r}11.9 \\
2.1\end{array}$ \\
\hline BSF & 23 & 2 & 43 & 0.61 & 0.28 & 0.32 & 7.6 \\
\hline BJ & 24 & 2 & 46 & 0.48 & 0.21 & 0.26 & 5.8 \\
\hline REC & 20 & 2 & 72 & 0.92 & 0.19 & 0.73 & 10.2 \\
\hline DC & 22 & 2 & 72 & 0.76 & 0.17 & 0.58 & 8.1 \\
\hline $\mathrm{JJ}$ & 19 & 2 & 74 & 0.59 & 0.16 & 0.43 & 5.8 \\
\hline $\mathrm{FF}$ & 23 & 2 & 95 & 0.91 & 0.43 & 0.48 & 5.0 \\
\hline VR & 25 & 2 & 65 & 0.94 & 0.47 & 0.46 & 7.2 \\
\hline AGP & 23 & 2 & 103 & 0.99 & 0.32 & 0.67 & 6.5 \\
\hline Mean & 22 & & 71 & 0.78 & 0.28 & 0.49 & 7.0 \\
\hline & & & & 0.18 & & & 1.6 \\
\hline
\end{tabular}

All studies were done in at least duplicate; the results shown are the averages of all determinations on an individual patient. Volumes are in BTPS.

$(11.9 \mathrm{ml} / \mathrm{kg})$ are nearly identical, whereas in the anemic patients $(7.0 \mathrm{ml} / \mathrm{kg})$ are significantly smaller.

D. Reproducibility. Reproducibility of $\mathrm{NLO}_{2}$ measurements in man was evaluated in the studies indicated in Table III. The reproducibility of lung volumes, on which the $\mathrm{LO}_{2}$ calculations were based, was within $10 \%$. The mean of eight successive determinations of $\mathrm{NLO}_{2}$ over a period of $1 \mathrm{yr}$ in one individual (CEC) was $970 \mathrm{ml}$, (range,
$740-1110 \mathrm{ml}$ ). The standard deviation was \pm 135 $\mathrm{ml}$, giving a coefficient of variation of $15 \%$. Three successive determinations of $\mathrm{NLO}_{2}$ in normal individuals (JBLG and MA) yielded values of 680 , 780 , and $750 \mathrm{ml}$ and 830,750 , and $750 \mathrm{ml}$, respectively. The mean of the absolute values of the difference of the duplicate estimates of $\mathrm{NLO}_{2}$ in the other normal subjects shown in Table IV was $115 \mathrm{ml}$ (range, $10-300 \mathrm{ml}$ ). The mean of the absolute values of the difference of the duplicate

TABLE IV

Comparison between Theoretical Estimates of $\mathrm{O}_{2}$ Stores and Experimentally Obtained Mean $\mathrm{O}_{2}$ Stores in Normal Man

\begin{tabular}{|c|c|c|c|c|c|c|c|c|c|c|c|}
\hline \multicolumn{8}{|c|}{ Theoretical $\mathrm{O}_{2}$ stores in a $70 \mathrm{~kg}$ man (1) } & \multicolumn{4}{|c|}{$\begin{array}{l}\text { Experimentally determined } \mathrm{O}_{2} \text { stores for a } \\
72 \mathrm{~kg} \text { man (present data) }\end{array}$} \\
\hline Dissolved & Myogloblin & Blood & Lung & $\mathrm{NLO}_{2}$ & $\mathrm{NLO}_{2} / \mathbf{k g}$ & $\mathrm{TBO}_{2}$ & $\mathrm{TBO}_{2} / \mathbf{k g}$ & $\mathrm{NLO}_{2}$ & $\mathrm{NLO}_{2} / \mathbf{k g}$ & $\mathrm{TBO}_{2}$ & $\mathrm{TBO}_{2} / \mathrm{kg}$ \\
\hline 60 & 280 & 1030 & 430 & 1370 & 20 & 1800 & 26 & 840 & $11.9 \pm 2.1$ & 1150 & 16 \\
\hline
\end{tabular}

The theoretical stores were converted from STPD to BTPS by multiplying by 1.17 . The experimentally determined stores represent the mean determinations from Table III. For comparative purposes, attention is directed at the $\mathrm{NLO}_{2}$ values, as lung volume measurements were not accomplished at comparable lung volumes. 
estimates in the anemic patients was $91 \mathrm{ml}$ (range, 3-244 ml).

\section{DISCUSSION}

The assumptions implicit in the use of tracer substances, particularly gases, in the measurement of body spaces have been extensively discussed (5-9). The specific use of the dilution of ${ }^{18} \mathrm{O}_{2}$ for the simplified determination of total body $\mathrm{O}_{2}$ stores by equation 7 involves the following assumptions which require discussion for evaluating the results obtained in these studies :

(1) Isotopic equilibrium between the external circuit and all body compartments is achieved during the period of study.

(2) The equilibrium ratio of $\mathrm{F}^{18} \mathrm{O}_{2} / \mathrm{F}^{16} \mathrm{O}_{2}$ is achieved instantaneously at the tissue sites of $\mathrm{O}_{2}$ utilization.

(3) There is no differential utilization of ${ }^{18} \mathrm{O}_{2}$ as compared with ${ }^{16} \mathrm{O}_{2}$.

Isotopic equilibrium. The calculation of $\mathrm{TBO}_{2}$ requires the assumption that equal $\mathrm{F}^{18} \mathrm{O}_{2} / \mathrm{F}^{16} \mathrm{O}_{2}$ ratios are achieved in the external system and the different body compartments. Failure to achieve equilibrium would result in an external ratio that was too high and lead to an underestimate of $\mathrm{TBO}_{2}$. With respect to this assumption, these studies show that, even after $20 \mathrm{~min}$, arterial and mixed venous ratios are somewhat lower than those found in the external system. Presumably, this failure of equilibration may be accounted for by the distribution of ${ }^{18} \mathrm{O}_{2}$ to areas with low $\mathrm{O}_{2}$ exchange rates or to methodologic problems of measuring the isotope ratios in gases extracted from blood. However, there are several findings which indicate that the error introduced by this failure of equilibration is small. At the end of a 5 min rebreathing period, arterial and mixed venous blood $\mathrm{F}^{18} \mathrm{O}_{2} / \mathrm{F}^{16} \mathrm{O}_{2}$ ratios averaged 0.99 and 0.965 of the ratios found in the external system, respectively. Further, the data show that a minimal value for $\mathrm{F}^{18} \mathrm{O}_{2} / \mathrm{F}^{16} \mathrm{O}_{2}$ is reached by $5 \mathrm{~min}$ in the external rebreathing circuit and that there is no significant change in the value thereafter. A significant failure to achieve equilibrium would be manifested by a progressively falling value of $\mathrm{F}^{18} \mathrm{O}_{2} / \mathrm{F}^{16} \mathrm{O}_{2}$ in the external circuit, and this was not observed. Moreover, since statistically there is no decrease in this ratio in the external circuit from 5-20 min, the volume of $\mathrm{O}_{2}$ in any areas of low $\mathrm{O}_{2}$ exchange rates must be too small to affect the calculated $\mathrm{TBO}_{2}$ significantly.

This observation of rapid virtual equilibrium is in accord with the data of other workers. Lassen et al. (10) and Dyson, Sinclair, and West (11) showed the near equilibrium of alveolar gas and arterial blood for tracer isotopic $\mathrm{O}_{2}$ occurred during one passage of blood through the normal lung, whether the isotopic tracer was introduced into venous blood (Lassen et al. [10]) or into alveolar air (Dyson et al. [11]). The striking rapidity with which isotopic tracer $\mathrm{O}_{2}$ could exchange with tissue $\mathrm{O}_{2}$ in the peripheral capillary bed was shown by Dollery and West (12). An appreciable fraction of ${ }^{15} \mathrm{O}^{16} \mathrm{O}$ inhaled was transported, mixed, diffused to cell sites of $\mathrm{O}_{2}$ consumption, metabolized, and diffused back into the plasma as metabolic $\mathrm{H}_{2}{ }^{15} \mathrm{O}$ in $30 \mathrm{sec}$. It appears that the failure to fully achieve this assumption does not introduce substantial error in the determination of $\mathrm{TBO}_{2}$.

Instantaneous equilibration of ${ }^{18} \mathrm{O}_{2}$ at tissue sites. This assumption is required to calculate the amount of ${ }^{18} \mathrm{O}_{2}$ that is consumed during the period of equilibration (and is not available for dilution). ${ }^{18} \mathrm{O}_{2}$ undergoes rapid utilization during its period of distribution throughout $\mathrm{TBO}_{2}$. At time zero there is no ${ }^{18} \mathrm{O}_{2}$ at the tissue $\mathrm{O}_{2}$ consuming sites and no ${ }^{18} \mathrm{O}_{2}$ is being consumed. As equilibrium is approached, ${ }^{18} \mathrm{O}_{2}$ tensions progressively increase until the equilibrium value is achieved. At equilibrium the amount being consumed can be accurately approximated by $(r)_{t=\text { equilibrium }} \times \mathrm{V}^{16} \mathrm{O}_{2} \times t$. There is no precise way of estimating the exact value of $\mathrm{V}^{18} \mathrm{O}_{2}$ during the equilibration period. However, it is probable that the true value of $(r)$ during the equilibration time lies between its value in arterial blood, $\left(r_{\mathbf{a}}\right)$, and its value in mixed venous blood, $\left(r_{\bar{v}}\right)$. To estimate the probable error involved, mean values of $\left(r_{\mathbf{a}}\right)$ and $\left(r_{\bar{v}}\right)$ during the experimental period, $\left(\bar{r}_{\mathrm{a}}\right)_{t=0-5 \mathrm{~min}}$ and $\left(\bar{r}_{\overline{\mathrm{v}}}\right)_{t=0-5 \mathrm{~min}}$, were obtained during the 5 min equilibration periods in four dogs by graphic integration. The value of $\mathrm{V}^{18} \mathrm{O}_{2} \times t$ calculated from $\left(\bar{r}_{\mathrm{a}}\right) \times \mathrm{V}^{16} \mathrm{O}_{2} \times t$ and from $\left(\bar{r}_{\bar{v}}\right) \times \mathrm{V}^{16} \mathrm{O}_{2} \times t$ should respectively represent maximal and minimal values for ${ }^{18} \mathrm{O}_{2}$ consumption during the experimental period. As shown in Table I, the calculated $\mathrm{NLO}_{2}$ based on these two values of $\mathrm{V}^{18} \mathrm{O}_{2}$ have a range of $58 \%$. A priori, it 
would appear that the values based on $\left(\bar{r}_{\mathrm{a}}\right)$ are closer to the desired tissue values, since the mixed venous blood compartment functions as a reservoir of $\mathrm{O}_{2}$ and not as a gas exchange compartment. Thus, the assumption that $\mathrm{V}^{18} \mathrm{O}_{2}$ equals $\left(r_{\text {e.c. }}\right)_{t=\text { equilibrium }} \times t$ overestimates the actual $\mathrm{V}^{18} \mathrm{O}_{2}$ and results in an underestimate of $\mathrm{TBO}_{2}$ (see equations $3-7$ ).

Isotope effect. The theoretical derivation of equation 3 assumes that tissue utilization of the two isotopic $\mathrm{O}_{2}$ species, ${ }^{16} \mathrm{O}_{2}$ and ${ }^{18} \mathrm{O}_{2}$, are proportional to their respective concentrations at utilization sites. This assumption must be evaluated in terms of possible isotope fractionation effects (13). Isotope fractionation refers to the effects on chemical and physical properties produced by changes in mass. Indeed, small isotopic fractionation effects producing a difference in the order of $1.5 \%$ in favor of ${ }^{16} \mathrm{O}^{16} \mathrm{O}$ utilization as compared to ${ }^{18} \mathrm{O}^{16} \mathrm{O}$ utilization have been reported in a number of biological systems (14). It might be expected that biological systems would then show preferential utilization of ${ }^{18} \mathrm{O}^{18} \mathrm{O}$ as compared to ${ }^{16} \mathrm{O}^{16} \mathrm{O}$. No data are available concerning metabolism of ${ }^{18} \mathrm{O}^{18} \mathrm{O}$. An isotope fractionation effect would be shown in the present study by a progressively increasing $\mathrm{F}^{18} \mathrm{O}_{2} / \mathrm{F}^{16} \mathrm{O}_{2}$ in the external rebreathing system with time. No such increases were observed. This would indicate that $(1){ }^{18} \mathrm{O}_{2}$ does not show any fractionation effect; (2) the isotope effect was too small to demonstrate with the technique used; or (3) the effect was cancelled out by failure to achieve complete equilibrium, which would have produced a progressive decrease in the $\mathrm{F}^{18} \mathrm{O}_{2} / \mathrm{F}^{16} \mathrm{O}_{2}$ ratios in the external circuit. In any event, equilibrium was achieved as judged by a stable ratio in the external circuit, indicating the validity of the reported method for determination of body stores.

The present treatment of the body lung-bloodtissue exchangeable $\mathrm{O}_{2}$ stores as a single compartment which reaches intantaneous equilibration with the external rebreathing system has been selected because it simplifies the determination of $\mathrm{TBO}_{2}$. Such an approach has several advantages. It permits the rebreathing of small initial volumes, with resultant large changes in $\left(r_{\text {e.c. }}\right)$ lessening the error in the determinations of $\mathrm{F}^{18} \mathrm{O}_{2} / \mathrm{F}^{16} \mathrm{O}_{2}$ ratios. As is evident from equation 7 , the measurement of ${ }^{16} \mathrm{O}_{2}$ consumption, and changes occurring in the
${ }^{16} \mathrm{O}_{2}$ stores during the rebreathing period, do not effect the measurement of exchangeable ${ }^{18} \mathrm{O}_{2}$ stores by this method. Furthermore, it avoids the necessity of blood sampling.

To our knowledge, body $\mathrm{O}_{2}$ stores have not previously been determined experimentally. However, there are a number of $a$ priori estimates available in the literature $(1,15)$. Table IV presents a comparison of one such estimate with the data found in the present study. In general, our experimentally determined values are lower than those based on theoretical estimates.

The difficulties inherent in theoretical estimates are considerable. Such estimates require a division of blood $\mathrm{O}_{2}$ stores into two compartments, one compartment containing blood with an $\mathrm{O}_{2}$ saturation of arterial blood and the other containing blood with the $\mathrm{O}_{2}$ saturation of mixed venous blood. It is impossible to fractionate accurately how much of the total blood volume is present in each compartment. The calculation of total stores is quite sensitive to the figures arbitrarily assigned to this fractionation. It is likewise difficult to estimate the mean $\mathrm{O}_{2}$ saturation in all the regional venous reservoirs. In addition, estimates of body $\mathrm{O}_{2}$ stores have, in general, included estimates of the $\mathrm{O}_{2}$ stores in myoglobin. However, because of the high affinity of myoglobin for $\mathrm{O}_{2}$, the precise quantity of $\mathrm{O}_{2}$ stores to ascribe to this compartment is difficult to ascertain (16).

Finally, as pointed out above, the present measurements represent the rapidly exchangeable $\mathrm{O}_{2}$ stores. Conceivably, total stores might be somewhat larger. It should be pointed out that, from the physiological standpoint, it is the rapidly exchangeable stores that are of primary interest with respect to survival during severe $\mathrm{O}_{2}$ depletion. These stores are the stores which are available to the organism to maintain viability during $\mathrm{O}_{2}$ deprivation. In this respect, survival time after loss of external $\mathrm{O}_{2}$ supply in man is approximately $4 \mathrm{~min}$, a time period at which the approximate 1 liter of $\mathrm{O}_{2}$ stores in man would be expected to become exhausted. Measurements of $\mathrm{TBO}_{2}$ in the harbor seal by our group have shown that these animals have a substantially larger $\mathrm{TBO}_{2}$ than man on a weight basis. The maximal diving time compatible with survival in this animal is $20 \mathrm{~min}$, a period of time at which the $\mathrm{O}_{2}$ stores would become entirely exhausted (17).

Total Body Exchangeable $\mathrm{O}_{2}$ Stores 
The measurements of $\mathrm{O}_{2}$ stores in the anemic patients were performed to test the ability of this method to demonstrate differences in the amount of $\mathrm{TBO}_{2}$ under circumstances in which $\mathrm{TBO}_{2}$ should be less than normal, as well as to provide data concerning $\mathrm{TBO}_{2}$ in severe anemia. These data clearly show that in patients with hematocrits of $25 \%$ or less, there is a sharp reduction of total $\mathrm{O}_{2}$ stores. In the face of total loss of external $\mathrm{O}_{2}$ supply, patients with hematocrits of approximately $25 \%$ would be expected to survive approximately $2.5 \mathrm{~min}$, rather than $4 \mathrm{~min}$. The method has therefore been used under circumstances of normal stores, increased stores (seals), and decreased stores (anemia) with apparent consistent results. It appears that this method should be applicable to the quantitative evaluation of patients with hypoxic diseases. This method may be useful in clarifying a number of physiological problems in the area of oxygen transport and metabolism. Such diverse problems as the quantity of $\mathrm{O}_{2}$ available to patients with secondary polycythemia, the amount of $\mathrm{O}_{2}$ in the developing fetus, and the clinical evaluation of patients with various hypoxic diseases may be approached by the method described here. In addition, the methodology should be applicable to studies of regional $\mathrm{O}_{2}$ metabolism employing isotopic ${ }^{18} \mathrm{O}_{2}$.

\section{ACKNOWLEDGMENTS}

We gratefully acknowledge the analytical assistance and helpful advice provided to us by Gerry K. Buzzard and Dr. Robert H. Schuler of the Mellon Institute Radiation Research Laboratories.

This investigation was supported by grant HE-05059 from the National Institutes of Health. Doctors Cross, Packer, and Altman were research fellows of the U. S. Public Health Service.

\section{REFERENCES}

1. Rahn, H. 1963. Oxygen stores of man. In Oxygen in the Animal Organism. Macmillan and Co., New York. 609.
2. Standardization of definitions and symbols in respiratory physiology. 1950. Federation Proc. 9: 602.

3. Comroe, J. H., Jr., editor. 1950. Pulmonary function tests. In Methods in Medical Research. Year Book Publishers, Inc., Chicago. 2: 74.

4. Dole, M. 1952. The chemistry of the isotopes of oxygen. Chem. Rev. 51: 263.

5. Eger, E. I., II. 1963. A mathematical model of uptake and distribution. In Uptake and Distribution of Anesthetic Agents. E. M. Papper and R. J. Kitz, editors. McGraw-Hill Book Co., Inc., New York. 72.

6. Kety, S. S. 1951. The theory and applications of the exchange of inert gas at the lungs and tissues. Pharmacol. Rev. 3: 1 .

7. Riggs, D. S. 1963. The Mathematical Approach to Physiological Problems: a Critical Primer. Williams \& Wilkins Co., Baltimore.

8. Sapirstein, L. A., and E. Ogden. 1956. Theoretic limitations of the nitrous oxide method for the determination of regional blood flow. Circulation Res. 4: 245.

9. Wrenshall, G. A. 1955. Working basis for the tracer measurement of transfer rates of a metabolic factor in biological systems containing compartments whose contents do not intermix rapidly. Can. J. Biochem. Physiol. 33: 909.

10. Lassen, N. A., H. W. Fritts, Jr., P. R. B. Caldwell, C. Giuntini, W. Dansgaard, and A. Cournand. 1965. Intrapulmonary exchange of the stable isotope ${ }^{18} \mathrm{O}_{2}$ injected intravenously in man. J. Appl. Physiol. 20: 809.

11. Dyson, N. A., J. D. Sinclair, and J. B. West. 1960. A comparison of the uptakes of oxygen-15 and oxygen-16 in the lung. J. Physiol. (London). 152: 325.

12. Dollery, C. T., and J. B. West. 1960. Metabolism of oxygen-15. Nature. 187 : 1121.

13. Bowen, H. J. M. 1966. Biological fractionation of isotopes. In Trace Elements in Biochemistry. Academic Press Inc., New York. 135.

14. Lane, G. A., and M. Dole. 1956. Fractionation of oxygen isotopes during respiration. Science. 123: 574.

15. Dejours, P. 1966. Respiration. Oxford University Press, New York. 25.

16. Farhi, L. F., and H. Rahn. 1955. Gas stores of the body and the unsteady state. J. Appl. Physiol. 7: 472.

17. Cross, C. E., B. S. Packer, M. Altman, J. B. L. Gee, H. V. Murdaugh, and E. D. Robin. 1967. Determination of total body Oxygen stores in normal man and seal. J. Clin. Invest. 46: 1048. (Abstr.) 